\title{
Hermeneutical Circle in Understanding \\ On an Original Link between Hermeneutics ANd Logic in the Heidegger - GADAMER Dialogue
}

\section{ZSUZSANNA MARIANN LENGYEL}

\begin{abstract}
The hermeneutical circle is one of the most fundamental but up to now contentious doctrines with a long tradition in the history of hermeneutics. In what follows, the purpose of my contribution is to reconsider the Heidegger-Gadamer dialogue on the circle (Zirkel, Zirkelhaftigkeit), with an emphasis on how they shed new light on the whole issue.

Keywords circle, prejudices, humanism, hermeneutics, logic, rhetoric, Gadamer, Heidegger
\end{abstract}

\section{Introduction}

In the case of Heidegger and Gadamer, the issue of the hermeneutical circle (in other words: the whole idea of the circular structure of interpretation) is about the close interrelation between understanding and prejudices, i.e. about the idea that the entire process of understanding includes certain preliminary expectations. I will argue that their dialogue on the circle led to the discovery of an original link between hermeneutics and logic. (I) First of all, I shall make a brief presentation of the conceptual background rooted in Antiquity of the circle whose criticism led to the two different hermeneutic accounts of circle. (II-III) Then I shall try

\footnotetext{
* doi: 10.26424/philobib.2018.23.1.05

Eötvös Loránd University, Budapest, lengyelzsm@gmail.com. My paper was supported by the research project No. PD 121045 of the National Research, Development and Innovation Office (NKFI-OTKA). I have used the text of my lecture held at the Annual Conference of International Society for Hermeneutics and Science (ISHS), organized by the University of Vienna, the Medical University of Vienna, the Corvinus University and the Eötvös Loránd University, Baden (Austria), August 22-24, 2017.
} 
to expound the way in which Heidegger transformed the classical concept of the circle as a mode of thought, first in 1927 when he introduced his famous discussion on the hermeneutic circle in $\S 32$ of Being and Time (and the auxiliary paragraphs: $\S 23, \S 2$ etc.). Afterwards, I shall analyse the way in which, in dialogue with Heidegger, Gadamer re-conceptualized the previous starting point in the chapter on the hermeneutic experience of his Truth and Method (entitled "The Hermeneutical Circle and the Problem of Prejudices") with the aim of justifying the model of knowledge applied by the humanities.

\section{The origins of the circle and the history of hermeneutics}

\section{The circle as an epistemological problem}

Both Heidegger and Gadamer distanced themselves from that circularity whose emergence can be traced back to the logical tradition, especially to Aristotle's logic and his theory of the ancient syllogism, whereas the circle implies the presence of a flaw in our thinking or an erroneous means of formal argumentation. ${ }^{1}$ In classical logic, the circle is only used in a negative sense, as a circulus vitiosus. It means a circular reasoning (or reasoning in a circle $)^{2}$, which occurs in a formal argument or in a definition of the concept. It is also known as paradoxical thinking. Such a circle is to be avoided as it violates the laws of logics. Petitio principii is one of the forms of circular reasoning which can be translated to "begging the question", as well as "assuming the initial point". The meaning given by Aristotle ties to the type of dialectical argument discussed in Book II of his Topics, where the false reasoning lies in the fact that the original point had already been constructed in the desired conclusion. The arguer uses the basic statement itself to verify that, or in inversed form, the arguer excludes from the argument even what he wants to refute. The term "idem per idem" also refers to a similar process which is a certain kind of tautology from the Bible. It means that we attempt to verify the same for the same, so we add no new component to the consideration of the thing. This "logical" form or idiom appears in the revelation of God's name, when God says "I will be what I will be", ${ }^{3}$ in the book of Exodus.

The logical concept of the circle can also be found in the modern theory of science; however, it also exists as a metaphysical metaphor, in this broader sense the circle as a vicious and devilish circle first appeared in Horace's Ars poetica. Horace was the first who described

\footnotetext{
${ }^{1}$ See: Aristotle, Prior Analytics, trans. Robin Smith (Cambridge: Hackett Publishing Company, 1989), 9091. (Another edition: Aristotle, The Categories, On Interpretation, Prior Analytics, Book II 16, reprinted ed. by Harold P. Cook and Hugh Tredennick (London/ Cambridge: Williem Heinemann Ltd. - Harvard University Press, $1962^{3}$ ) 485, 487, 489, 65a4-7 and 64b28-65a26.

2 "Zirkel im Beweis" and Heidegger, Sein und Zeit $17^{\text {th }}$ ed., (Tübingen: Niemeyer, 1993) 11. Translation: Idem, Being and Time, trans. Joan Stambaugh (Albany, N.Y.: State University of New York Press, 1996) 6.

${ }^{3}$ Quoting Exodus 3:14, 33:19
} 
the disappointing situation in which a series of events can become negative circumstances by making an existential state or a given condition progressively worse. Each recurrence of problems reinforces the previous one, that is, the troubles return cumulatively within the same logic. This fatal connection between cause and effect - where each outcome must further increase the effectiveness of causality - also entered the fields of philosophy, theology, mathematics, economy and, last but not least, the pathology of medicine.

Consequently, it is important to note that Kant integrated a positive approach of this logic, by using the circle within antinomic oppositions of the Critique of Pure Reason and thereby he almost anticipated the solution of the issues raised by Heidegger and Gadamer. In the chapter Antinomies, Kant discovered the contradictions in our pure reason, contradictions which he believed to be in accordance with the human nature of reason. Furthermore, in the chapter Doctrine of Dialectics concerning the traditional domains of metaphysica specialis (psychological, cosmological and theological ideas), he revealed the transcendental illusions through which we let ourselves divert from the experimental use of reason. These illusions give us the hope that we can expand the scope of our pure reason beyond the limits of all possible experiences. This kind of circularity in both antinomies and transcendental illusions involves a logic moving in a cycle or a logical circularity. However, from Kant's viewpoint, this type of circularity is neither a logical fallacy nor a lack of logic, but it is inherent in the nature of our finite human reason and it can be described as a natural state of reason. The system of thought in Heidegger's hermeneutical circle will be developed from the critique of this logical tradition and from its radicalization.

\section{The circle in the humanistic tradition}

In contrast with Heidegger, Gadamer is determined by another direction, namely by the ancient classical rhetoric which has also known a kind of circularity - it has been simply regarded as a rule (die Regel) ${ }^{4}$ applied to the relation between the whole and its parts, since the rhetoricians compared the perfect speech with an organic body (with the relationship

\footnotetext{
${ }^{4}$ See Hans-Georg Gadamer, "Vom Zirkel der Verstehen (On the Circle of Understanding)" in Gesammelte Werke 2. Hermeneutik II. (Tübingen: J. C. Mohr (Paul Siebeck), 1993) [henceforth referred to as GW 2] 57.: "Die hermeneutische Regel, daß man das Ganze aus dem Einzelnen und das Einzelne aus dem Ganzen verstehen müsse, stammt aus der antiken Rhetorik...(The hermeneutical rule that we must understand the whole, from the individual and the individual from the whole stems I from ancient rhetoric" (emphasis added). Bibliographical note: Gadamer's complete works are cited with the abbreviation GW (Gesammelte Werke 1-10. Tübingen: J. C. Mohr (Paul Siebeck) from 1985 to 1995) followed by volume number, comma and page numbers. All emphasis is original unless otherwise specified. If there are references to both the original German text and the corresponding English translation, they are separated for example as follows [GW 1, 376. In English: 364.].
} 
between head and limbs ["mit... dem Verhältnis von Haupt und Gliedern"]). ${ }^{5}$ At this point, the ancient humanistic tradition was combined with the new endeavours of the Reformation. "Luther and his successors transferred this image, familiar from classical rhetoric to the process of understanding and they developed the universal principle of textual interpretation." ${ }^{6}$ Within the outlines of this approach, the circle has a philological meaning that refers to a type of writing and of understanding the texts in which a unity (composition, coherence) is created between the whole (universum) and the parts (regions). The same rule must have been applied both in the case of the Bible and the classical texts: the parts of a text can be understood within the whole and vice versa: the whole with its parts. The German classical philologist August Boeckh used the German term "hermeneutische Cirkel" in his lectures entitled "Enzyklopädie und Methodologie der philologischen Wissenschaften" in 1809.' Nevertheless, Schleiermacher thematically formulated the methodological principle of the circle which surpassed the circular interplay of understanding the whole and the parts. ${ }^{8}$ Dilthey himself also participated in the dispute on the circle, ${ }^{9}$ which became an integrative part of the hermeneutic debates of the $19^{\text {th }}$ century, but he partially stressed his suspicion that the "circularity" (Zirkelhaftigkeit) can be seen as an "aporia" or a "danger" of subjectivity in hermeneutics. Dilthey's lifework further preserved the idea that knowledge reached its peak in the age of the Enlightenment, which is why he regarded as problematic the situation in which the interpreter's knowledge was led by certain pre-suppositions, anticipations and personal interests.

\section{The hermeneutic circle in Heidegger's approach}

\section{Intuition and phenomenological sight}

Heidegger completely transformed the classical concept of the circle as a model of thought, first in 1927 when he introduced his famous discussion on the hermeneutic circle in $\S$

\footnotetext{
${ }^{5}$ For further information, see Hans-Georg Gadamer, Gesammelte Werke 1: Hermeneutik I. Wahrheit und Methode, (Tübingen: J. C. Mohr (Paul Siebeck) 1990) [henceforth: GW 1] 179. Translation: Idem, Truth and Method, Second edition, trans. and revised by Joel Weisheimer and Donald G. Marshall, (London, New York: Continuum, 2006) 176.

${ }^{6}$ Gadamer, GW 1, 179. [In English: 176-177.]

7 August Boeckh, Encyklopädie und Methodologie der philologischen Wissenschaften, Nachdruck. (Darmstadt, 1966) 102, 109, 125, 131, 139, 140, 142.: "hermeneutische Cirkel".

${ }^{8}$ Cf. Friedrich Schleiermacher, Hermeneutik und Kritik, ed. Manfred Frank (Frankfurt am Main: Suhrkamp Verlag 1977).

9 Wilhelm Dilthey, "Die Entstehung der Hermeneutik", in Idem, Die geistige Welt. Einleitung in die Philosophie des Lebens. 1. Hälfte. (Gesammelte Schriften 5) Stuttgart/Göttingen: Taubner und Vandenhoeck \& Ruprecht, 1990) 317-338., here: 338.
} 
32 of Being and Time. At this point, primarily by criticizing Husserl's phenomenology, Heidegger was led to develop the hermeneutical circle as a fore-structure (Vor-struktur) of understanding, or in other words, he spoke of a circular structure that first of all makes the significance of the anticipatory nature of understanding (i.e. that of the "Entwurf'-character) visible and this circularity is an essential, positive part of his fundamental ontology concerning the understanding of the Being. At the turn of the century, Paul Natorp and Edmund Husserl's controversy was one of the most significant debates which arose together with the problematisation of being and possibility of intuition: the concept of "viewing" (Anschauung). Natorp and the Neo-Kantians rejected the possibility of intuition; by contrast, in Husserl's investigations, intuition appears as a source of knowledge.

With the help of rejecting the intuition, in his 1887 article entitled "On the Objective and Subjective Grounding of Knowledge", Natorp levelled a critique against Ernst Mach's empirical positivism of phenomenological physics; by contrast, Husserl attempted to appreciate the sense of "positivism" in an entirely new way. Turning against the Neo-Kantian epistemological-transcendental approach, Husserl claims that phenomenologists are genuine positivists (die echten Positivisten). ${ }^{10}$ Of course, this positivism is not identical with the positivism of the empirical sciences, limited to empirical experiences. On the contrary: phenomenology is a genuine transcendental positivism directed towards the positive gained from reductions. In fact, it scrutinises the problem of philosophising focussed on the thing (die Sache selbst), which for Husserl, in Ideen I, is the "principle of all principles" (Prinzip aller Prinzipien). ${ }^{11}$ The ultimate basis of knowledge is nothing other than a "genuine giving intuition" (originär gebende Anschauung). To return to the thing means to simply accept what presents itself to us by the "originally presentive" nature of intuition. The idea is not that Husserl practiced a phenomenology against logic, but at the core of his research on the origins or the event of pure phenomenalization, Husserl claims that there is no need to do logical and argumentative operations, but it should be our task to intuitively cover up the things themselves. For Husserl, the "normal" means of approaching our experience through the natural disposition differs from the phenomenological intuition; however, we can shift our attention towards the mode of experience through a phenomenological disposition, in order to gain the ability of intuition in a transcendental sense or to let ourselves be guided by the things themselves. Husserl expressed a maxim that can be formulated thus: "Back to the things themselves!" It had a liberating power for the members of the Phenomenological Movement, and at the same time, it meant leaving any subjectivism behind and turning to the objects. In Husserl's transcendental method, its phenomenological character is to be given by an eidetic method which leads to intuition and to the original giving of the things themselves.

10 Edmund Husserl, Ideen zu einer reinen Phänomenologie und Phänomenologischen Philosophie. I. Allgemeine Einführung in die reine Phänomenologie (Tübingen: Niemeyer, 2002), 38.

${ }^{11}$ Husserl, Ideen I, 43. 


\title{
Phenomenological sight and hermeneutical circle
}

The phenomenological intention that remained very productive for Heidegger was formulated thus: "to let ourselves be guided by the things themselves" in understanding, but unlike the "phenomenological sight" introduced by Husserl, Heidegger referred to a "hermeneutical circle". The problematic point is that the expressions "das Gegebene", "Geben", "Es gibt" and "Gabe", hermeneutically speaking, have completely different meanings than in phenomenology. In Heidegger's work, the givenness is something preliminarily given (Vorgegeben), something given (als etwas gegeben), we are always beyond a pure or a final givenness. In Heidegger's view, Husserl's notion of intuition conflicts with the fact that the things always come to be accessible to us in a kind of interpretative way, therefore all human understanding transcends the given things. We cannot meet the things in their objective skeletonised, unpainted being, but rather we understand them as something (etwas als etwas). So much so, that even this grasping of something which is free of the "as"-structure must be a privation of seeing, a non-understanding in Being and Time. ${ }^{12}$ The hermeneutic feature of Heidegger's phenomenology is equally due to rendering questionable the "pure" description (free of any act of interpretation) and the 'immediateness' according to classical Husserlian phenomenology. There is no "pure" description, everything is "contaminated", i.e. every description has already been "infected" with interpretations. Our understanding is characterized by a threefold circular structure: these are the "fore-having," "fore-sight," and "fore-conception" ("Vorhabe," "Vorsicht," "Vorgriff,"), ${ }^{13}$ and through this circularity Heidegger clearly demonstrates that a hermeneutic dimension is crucial to the structure of the experience. As Heidegger would say, not even a primary experience could ever be a form of "pure" seeing or intuition, since it bears a structure of interpretation from the very start; thus, the idea of unprejudicedness desired by both Descartes and Husserl is only one of many other prejudices.

\begin{abstract}
"Interpretation is never a presuppositionless grasping of something previously given. When the... interpretation likes to appeal to what "is there, " what is initially "there" is nothing else than the self-evident, undisputed prejudice of the interpreter, which is necessarily there in each point of departure of the interpretation as what is already "posited « with interpretation". ${ }^{14}$
\end{abstract}

Heidegger asked whether we should accept the phenomena as "finalities", or the phenomena showed a kind of connection with the anticipatory and projecting character of understanding

\footnotetext{
${ }^{12}$ Heidegger, Sein und Zeit, (§ 32) 148. [In English: 140.]

${ }^{13}$ Heidegger, Sein und Zeit, (§ 32) 150. [In English: 140-141.]

${ }^{14}$ Heidegger, Sein und Zeit, (§ 32) 150. [In English: 141.]
} 
(with the so-called Entwurf-character). Through the hermeneutical circle, Heidegger states that something we see as a pre-given is in fact a "position", a "standpoint" which already operates as a prejudice. Here, the pre-given I have not understood before in its original sense is my own superficial knowledge. Understanding becomes an act of interpretation only if we are also aware of the constantly exercised self-understanding of understanding itself, that is, only if, in interpretation, our understanding can appropriate what has always already been understood and familiar. The "circle" belongs to the structure of meaning and simultaneously to the essence of understanding itself as a distinctiveness. Gadamer claims that Heidegger's deep insight culminated not so much in showing the circularity and making us aware of the circle, but in showing that "this circle possesses an ontologically positive significance". ${ }^{15}$

\section{Heidegger's critique of "prejudices": \\ Vormeinung and the problem of the inconstancy of the Self (Unselbständigkeit)}

Although the concept of "Vormeinung" applied by Heidegger essentially belongs to the circular structure of human understanding as an antecedent opinion, a prior assumption or a pre-judgment that the interpreter previously possessed, in Being and Time it has a negative or pejorative sense; occurs as a problem in $\S 25-27$, when Heidegger deals with the question of togetherness and community with others (Mitsein, Mitdasein). His discussion has explicitly turned to clarify an inadequate relationship with the Self and the possibility of its failure to stand by itself. In context of our Being-in-the-World, solitude (Einsamkeit) has been given priority over the public sphere - the publicness (Öffentlichkeit) and the world of the majority (die Welt der Vielen) -, whereas the latter indicated a fallen world closely tied to the world of inauthenticity, idle talk and the They (Uneigentlichkeit, Gerede, das Man). While solitude has a positive sense, "Being-alone is a deficient mode of being-with [others], its possibility is a proof for the latter", "[k]nowing oneself is grounded in primordially understanding being-with [others]". ${ }^{16}$ As a negative side of the being-with-others, Heidegger identified the dictatorship of the They (the Anyone) and a mass-media-instituted public sphere in which the "subject" of the everyday world is called the neuter (the They) and the human Dasein loses himself. ${ }^{17}$ In this everydayness, as Heidegger says, "the other can become one who is dependent and

\footnotetext{
${ }^{15}$ Gadamer, GW 1, 271. [In English: 269.]

${ }^{16}$ Heidegger, Sein und Zeit, (§ 26) 120; 124. [In English: 113; 116.]

17 "Distantiality, averageness, and levelling down, as ways of being of the they, constitute what we know as 'publicness'. Publicness initially controls every way in which the world and Da-sein are interpreted, and it is always right, not because of an eminent and primary relation of being to 'things,' not because it has an explicitly appropriate transparency of Da-sein at its disposal, but because it does not get to 'the heart of the matter', because it is insensitive to every difference of level and genuineness. Publicness obscures everything, and then claims that what has been thus covered over is what is familiar and accessible to everybody." (Heidegger, Sein und Zeit, (§ 27) 127. [In English: 119.])
} 
dominated even if this domination is a tacit one and remains hidden from him." ${ }^{18}$ This does not mean that we grow up thrown into our own historicity and that we never begin to think of the world through a tabula rasa. Rather, Heidegger's criticism is focused on how the foremeanings and prejudices have always had a serious impact on our life beyond all personal morality (conscience) or against our morality, too. Our life can be determined by the dictatorship of publicness in a way that, in this everydayness, no one is himself; in the impersonal world of the They-self "Da-sein is dispersed in the they and must first find itself", 19 e. g. the masses talk through us, too. Which is why we are also able to feel outraged by what the others do. The young Heidegger criticized the public sphere, that is, the They-world from a linguistic viewpoint. The rootlessness of language (the idle talk and public interpretedness) is going to generate the human means of relating to a world that would not have access to the phenomenon and that would lead to the unspoken dictatorship of publicness, over the things and to the levelling-down characteristic (Nivellierung) of the phenomenon.

Heidegger continues to be sceptical of any public interpretedness (öffentliche Ausgelegtheit), but, in his later works, he considers that it belongs to the technical world rather than to the Anyone-world.

The hermeneutical circle seems to be neither an epistemological problem, nor a methodological prescription but, as Gadamer points out, "a description of the way interpretive understanding is achieved". ${ }^{20}$ The circle belonging to the ontological structure of understanding has become a crucial part of Heidegger's fundamental ontology; he asserted that interpretation is not the acknowledgment of what has been understood, but rather the development of prior possibilities projected in understanding and the factical understanding itself is also achieved in the light of anticipations, pre-assumptions and fore-meanings, always based on some prior pre-cognition. The circle is not an inadequacy, but the self-understanding of our understanding - man always understands based on some presuppositions or prejudices. The ultimate goal is no longer to escape from this circle, but to enter it in the right way. ${ }^{21}$ In Heidegger's view, a concretion of the development of the hermeneutical circle appeared in his three Frankfurt lectures from 1936, entitled The Origin of the Work of Art, where Heidegger was partly influenced by Hegel's Lectures on Aesthetics. ${ }^{22}$

\footnotetext{
${ }^{18}$ Heidegger, Ibid, (§ 26) 122. [In English: 114.]

${ }^{19}$ Heidegger, Ibid, (§ 27) 129. [In English: 121.]

${ }^{20}$ Gadamer, GW 1, 271. [In English: 269. - Italics modified]

${ }^{21}$ Heidegger, Sein und Zeit, (§ 32) 153. [In English: 143.]

22 "So we must move in a circle. This is neither ad hoc nor deficient. To enter upon this path is the strength, and to remain on it the feast of thought - assuming that thinking is a craft. Not only is the main step from work to art, like the step from art to work, a circle, but every individual step that we attempt circles within this circle." Heidegger, "The Origin of the Work of Art (1935-36)", in Off the Beaten Track ,trans. Julien Young and Kenneth Haynes, (Cambridge: Cambridge University Press, 2002), 1-85. here: 2.
} 
In short, not only the opinions but also the prior conditions of understanding were reconstructed in approaching the hermeneutical circle; in this sense, Heidegger's discussion contributed to the discovery of a hermeneutical "logic" from a trans-logical perspective, and it simultaneously offered access to an original link between hermeneutics and logic.

\section{The hermeneutical circle and the Problem of Prejudices in Gadamer}

In dialogue with Heidegger's approach, Gadamer re-conceptualized the hermeneutical circle in the chapter on the hermeneutic experience of his Truth and Method (under the title "The Hermeneutical Circle and the Problem of Prejudices"), while his aim was to justify the form of knowledge of humanities. Heidegger had still not spoken of prejudices at all in a literal sense of this word, but the discussion on this relevant issue took the form of a description of the "Vormeinung". On the one hand, Gadamer reinforced the consequences derived from Heidegger's initiative according to which there was never an absolute zero in understanding; in the absence of prejudices, we would not be able to understand anything - prejudices are the very conditions that make understanding possible and, in the end, they prove to be a source of knowledge or truth. On the other hand, he criticized the Heideggerian idea that the only one point in which our relationship with the tradition was determined by the undiscussed and the unconscious, the prevailing prejudices ("Vormeinungen") represented the Anyone-world in the dictatorship of publicness.

The hermeneutical circle was a central part of the whole realm of a theory of hermeneutic experience by explaining it in a way that Gadamer called the rehabilitation of prejudices. First and foremost by sketching the way in which this word received its contemporary negative meaning, Gadamer's basic attempt was to retrieve (wiedergewinnen) and rehabilitate other productive meanings of prejudices that are part of the tradition, but this approach is far from our way of thinking today. Gadamer managed to reconstruct a positive meaning of the prejudices, still regarded as a sinking stream in the mainstream of tradition.

What is at stake in his discussion is the means through which we are able to find a way to access our history and what the human sciences are generally about. "Our question is how hermeneutics... can do justice to the historicity of understanding." ${ }^{23}$ Furthermore, Gadamer outlined a main dilemma of whether both the "prejudices" (Vorurteil) and "the thing itself" (die Sache Selbst) should be valid synchronically. There are two main criteria: (1) the first, last and constant task is that every interpreter must direct his gaze "on the things themselves" and let himself be guided by the things, however, (2) the interpreter always understands based on

${ }^{23}$ Gadamer, GW 1, 270. [In English: 268.] 
some prejudices and, in Gadamer's formulation, we read "the text with particular expectations in regard to a certain meaning". ${ }^{24}$

This dilemma had already occurred in the Enlightenment and the modernity, since prejudices were discredited and completely exiled as a solution from the realm of scientific knowledge. ${ }^{25}$ The Enlightenment's basic belief was that a genuine science required freedom from prejudices. Husserl also took in a similar direction insofar as he kept in mind an understanding without any prejudices in his article Philosophy as a Rigorous Science about 1910-11. ${ }^{26}$ By considering philosophy to be a rigorous science, Husserl believed that man can be free from unexplored assumptions and unfounded postulates. ${ }^{27}$ Against him, Gadamer clearly argued that this issue was not a self-evident either/or question. There was also one prejudice of the Enlightenment that defined its essence: this fundamental prejudice was "the prejudice against prejudice itself", the overcoming of all prejudices or the absence of prejudices would also prove to be a prejudice; therefore, Gadamer emphasized that this is the point in which the attempt to critique this demand of the Enlightenment must start and revising it "opens the way to an appropriate understanding of the finitude" which dominates our humanity and our historical consciousness, since "the recognition that all understanding inevitably involves some prejudice gives the hermeneutical problem its real thrust" ${ }^{28}$

Without rehabilitating the prejudices, Gadamer goes so far as to say that we would ignore the access to our history and the possibility of knowing in humanities. The term "prejudice" in itself is a neutral expression that may have both a positive and a negative value. Even in the Enlightenment this word has acquired a negative connotation. Based on their sources, the Enlightenment made a distinction between the two types of prejudices: between (1) the prejudice due to human authority (/the prejudice from partiality) and (2) due to overhastiness, further modifying the scope of prejudices, it was restricted to the absence of a foundation. In doing so, something counts as a prejudice only if it has no foundation in the things themselves - i.e., if it is unfounded, a judgment made in the absence of proper consideration of the thing by assuming it uncritically. A global requirement was at that time that everything had already been decided before the judgment seat of reason, which only gave

\footnotetext{
${ }^{24}$ Gadamer, GW 1, 271. [In English: 269.]

${ }^{25}$ Gadamer, GW 1, 275-276. [In English: 273.]

${ }^{26}$ See H Edmund usserl, Philosophie als strenge Wissenschaft, ed. Wilhelm Szilasi (Quellen der Philosophie 1) (Frankfurt am Main: Vittorio Klostermann, 1965). The first 1965publication and its detailed analysis with afterword of the volume entitled Philosophy as a Rigorous Science is connected to Wilhelm Szilasi's name. This volume has been one of the most available editions of Husserl's works and hence many have quoted it.

${ }^{27}$ Cf. Edmund Husserl, Hua 1: Cartesianische Meditationen und Pariser Vorträge (Cartesian Meditations and the Paris Lectures), Husserliana, Bd. I, ed. Stephan Strasser. (Den Haag: Nijhoff, 1950) 6; 9; 25.

${ }^{28}$ Gadamer, GW 1, 274; cf. 280-281. [In English: 272 f.; cf. 277.]
} 
it legitimacy. The fact that the unfounded judgment may have been seen as a fallacy or error was problematic, the negative meaning of prejudices implied that they already always meant false judgment, the possibility that an unfounded judgment could also be truth was not taken into consideration. However, fluctuation can be experienced in several countries - while the Enlightenment in England and France militated for a complete freedom from prejudices, the German Enlightenment recognized that we have been educated with "truth prejudices", ${ }^{29}$ influenced by Luther's reformation activity. A justification through rational knowledge can never be achieved to its perfection. There are more things what we have to accept rather than to revise or dismiss in order to live our everyday lives. "That is why" writes Gadamer - "the prejudices of the individual, far more than his judgments, constitute the historical reality of his being. ${ }^{130}$

Referring to the word "prejudice" that stems from the Latin noun praejudicium, in the judiciary process the praejudicium simply meant a prejudgment as a provisional legal verdict (Vorentscheidung) before the final verdict was reached. Gadamer's main admittance is that besides all the negative consequences, it can also receive a positive meaning, insofar as there are legitimate prejudices (prejuges legitimes). In the interest of discovering a productive meaning of the prejudices, Gadamer separated what had merged into one another during the Enlightenment: he made a distinction between the dogmatic thinking and the prejudiced one. ${ }^{31}$ In fact, to criticize the prejudices is to criticize the dogmatic commitments, it is perhaps the reason why the prejudices had a negative sense. In his argument against the metaphysic dogmatism, Kant spoke of the maxim Sapere aude! "Dare to use your own reason" (/Dare to know!) while levelling a serious critique of the "Schwärmerei" as a form of wishful thinking (enthusiasm). ${ }^{32}$ In a broader sense, the Enlightenment's biblical criticism also struggled against the dogmatic claims of the Bible. In his 1986 article entitled Reason and Practical Philosophy, Gadamer's thesis was that dogmatism is not simply the issue of the content -: e. g. to dogmatically believe in something - but an attitude towards something (a kind of treatment of the questions). An anti-dogmatic way to discuss the questions is to continuously make the debate or even the epoche accessible to the discussion. The idea is to never accept something as a dogma, but to do so in the way that excludes the possibility of discussion. Gadamer does not consider the romantic critique of the Enlightenment to be a solution, because it also shared the pre-assumptions of the Enlightenment, by only reversing its values but adopting the

\footnotetext{
${ }^{29}$ Gadamer, GW 1, 277. [In English: 275.]

${ }^{30}$ Gadamer, GW 1, 281. [In English: 278.]

${ }^{31}$ Cf. Gadamer, GW 1, 274; 277 f. [In English: 272; 275 f.; 280.]

32 This is a metaphysical attitude which tends to transgress the laws of pure reason and its own boundaries.
} 
same schema, thus the Romanticism "itself ends the Enlightenment" while "it evolves as historical science". ${ }^{33}$

Dilthey and the Historical School are characterized by historicism: the past is regarded as something "historically" understandable. Gadamer saw this relation to the past not as the normal case of understanding that sees the other (the past, the text and the whole world) as an equal partner. Rather, the historical understanding is similar to the situation of exams, of legal interrogations or of therapies, i.e., it is an asymmetric case. In historicism, Gadamer criticized the craving for a pure objectivity. One cannot be an outsider as if reflected outside of the history of the world from a superposition; therefore the requirement of unprejudicedness or the discrediting of all prejudices only marks that we are still unaware of our finitude. Prejudices pertain to the historical structure of understanding, therefore all understandings should take account of their own prejudices. The core of the problem is not represented by the prejudices that we have, but "it is the pack of our non-recognized prejudices that makes us deaf to what speaks us in tradition". Hidden prejudices certainly dominate us from behind the scenes so that all understandings can be guided by them but changeable in no way. Even the hidden prejudices hinder us from letting ourselves be guided "by the thing itself"; by contrast, being aware of prejudices can offer us an openness towards the "thing" and a sensitivity towards the alterity of the text through a hermeneutically trained consciousness (ein hermeneutisch geschultes Bewußtsein). ${ }^{34}$ Gadamer uses the inversion of logic between the question and answer to explain the essence of historical understanding, the event character; in this sense Gadamer is committed to finite thinking. To understand a tradition is to understand the question what a response is. In a Gadamerian sense, a hermeneutically trained consciousness may be circumscribed by its relation to the prejudices, namely this understanding will be concerned not merely with forming its own anticipations but with becoming aware of them so as to verify them. The hermeneutical circle cannot exist without (1) "sensitivity" (Empfänglichkeit) or "hermeneutical goodwill" and (2) the "fore-conception of completeness" (Vorgriff der Vollkommenheit), which describe two sides of the same: the experience of concrete otherness that includes the entry into hermeneutics. "Every encounter with tradition ...involves the experience of a tension between the text and the present. The hermeneutic task consists in not covering up this tension by attempting a naive assimilation of the two but in consciously bringing it out." 35

The real place of the hermeneutic experiences is within the otherness that operates against our expectations in a both positive and negative sense. The encounter with tradition implies that something addresses us, calls for understanding but it is possible only when our own prejudices are properly brought into play and when it is put at risk and provoked. The

\footnotetext{
${ }^{33}$ Gadamer, GW 1, 280. [In English: 277.]

${ }^{34}$ Gadamer, GW 1, 273. [In English: 271.]

${ }^{35}$ Gadamer, GW 1, 311. [In English: 305.]
} 
encounter with a historical document, a foreign culture and its language, a cherished dream, or a meeting with the other can provide this provocation. The characteristic of this test lies in the process of questioning. Only in this process can we "distinguish [1] the true prejudices, by which we understand, from [2] the false ones, by which we misunderstand". "All understanding continuously forms fore-projections (Vorentwurf), but this is only anticipatory in nature if it is to be confirmed by the "things", therefore "[t]he only "objectivity" here is the confirmation of a fore-meaning in its being worked out". ${ }^{37}$ For Gadamer, it is crucial that the hermeneutical circle of understanding expands in concentric circles (in konzentrischen Kreisen), ${ }^{38}$ constantly widening the understood unity of meaning. In the hermeneutical circle, Gadamer allows us to envision the unity of meaning in terms of a reality; by contrast, it is no longer possible to affirm Hegel's absolute viewpoint positing the end of the history, because "the idea of an absolute reason is not a possibility for historical humanity". ${ }^{39}$

These arguments and consequences which Gadamer developed in the analysis of the circle in his Truth and Method generated a famous debate between Habermas and Gadamer during the 1960s and the 1970s, but this dispute would be the matter of a future investigation.

\section{Conclusion: on the relation between hermeneutics and logics}

Georg Misch (1878-1965) and Hans Lipps (1889-1941) already elaborated how logics may be intertwined with hermeneutics as a "hermeneutic logic" (hermeneutische Logik). In this respect, Gadamer also considered fundamental works ${ }^{40}$ both Misch's book titled Der Aufbau der Logik auf dem Boden der Philosophie des Lebens ${ }^{41}$ and Lipps' one titled Untersuchungen zu einer hermeneutischen Logik of $1938^{42}$, on which Otto Friedrich Bollnow wrote a significant critical interpretation. ${ }^{43}$ In the 1960 s and 1970s, after the publication of Truth and Method as its history of effect, as it is known, a broader discussion about the controversy of hermeneutics and logic unfolded between Gadamer, Habermas and later the Frankfurt School (Karl Otto

\footnotetext{
${ }^{36}$ Gadamer, GW 1, 304. [In English: 298. - Italics in original]

${ }^{37}$ Gadamer, GW 1, 272. [In English: 270.]

${ }^{38}$ Gadamer, GW 1, 57.

${ }^{39}$ Gadamer, GW 1, 280.: "Wenn das zutrifft, dann ist die Idee einer absoluten Vernunft überhaupt keine Möglichkeit des geschichtlichen Menschentums." [In English: 277.]

${ }^{40}$ Gadamer, "Die Hermeneutik und die Dilthey-Schule", in Idem, GW 10.: Hermeneutik im Rückblick, (Tübingen: J. C. Mohr (Paul Siebeck), 1990) 188.

${ }^{41}$ Georg Misch, Der Aufbau der Logik auf dem Boden der Philosophie des Lebens. Göttinger Vorlesunger über Logik und Einleitung in die Theorie des Wissens, ed. G. Kühne Bertram - Frithjof Rodi (Freiburg/München: Karl Alber Verlag, 1994)

${ }^{42}$ Hans Lipps, Werke II.: Untersuchungen zu einer hermeneutischen Logik. (Frankfurt am Main: Vittorio Klostermann, 1976).

${ }^{43}$ See also Otto Friedrich Bollnow, Studien zur Hermeneutik. Bd.2: Zur hermeneutischen Logik von Georg Misch und Hans Lipps, (Freiburg/München: Karl Alber Verlag, 1983).
} 
Apel, Rüdiger Bubner, Hans Joahim Giegel and Claus Bormann). The issue was whether to approach hermeneutics from an old traditional logical perspective, or if there was a "new" form of logic within hermeneutics, a hermeneutical "logic" beyond all controversy. This debate is still open today, but especially based on Heidegger's early works, Gadamer was capable of further thinking this issue and of increasing its productivity through the hermeneutic circle and the problem of prejudice. His approach went beyond the modern problem of method between the natural and human sciences and beyond the foundation-debate (Grundlagenstreite and Letztbegründungsansprüche) of the $20^{\text {th }}$ century. Heidegger left open the possibility of a new logic. Instead of logic, however, Gadamer reinforced the significance of the rhetorical tradition in hermeneutics and, starting from the guiding concepts of humanism, he highlighted the priority of "Bildung" and the importance of humanity (traced back to Hegel and Herder). Naturally, from a Gadamerian standpoint (within hermeneutics) the classical, formal logic is still valid, but the universality of hermeneutics will no longer depend on it. 